\title{
Effects of High Carbon Ferrochrome Additions on the Microstructure and Properties of Fe-C-Cr-Nb Hardfacing Alloys
}

\author{
Fei HUANG ${ }^{1,2 *}$, Renwei LI ${ }^{1}$, Zhen'an REN $^{3}$, Wumu LIU ${ }^{4}$ \\ ${ }^{1}$ Northeast Electric Power University, Engineering Training Teaching Center, No. 169 Changchun Road, Jilin, 132012, \\ China \\ ${ }^{2}$ Jilin Engineering Normal University, No. 3050 Kaixuan Road, Changchun, 130052, China \\ ${ }^{3}$ Jilin University, School of Materials Science and Engineering, No. 5988 Renmin Street, Changchun, 130022, China \\ ${ }^{4}$ BOSCH Automotive Parts (Changchun) Co., Ltd., Changchun 130012, China
}

crossref http://dx.doi.org/10.5755/j02.ms.23524

Received 04 June 2019; accepted 06 September 2019

\begin{abstract}
Fe-Cr-C-Nb hardfacing alloys composed of $1.07-1.33$ wt. $\%$ C, $0.08-2.61$ wt.\% $\mathrm{Cr}$, and $4.55-4.98$ wt. $\%$ Nb were prepared on C45E4 steel surfaces using alloy steel flux-cored wires. The alloy microstructures were studied by optical microscopy, scanning electron microscopy (SEM), transmission electron microscopy (TEM) and X-ray diffraction (XRD) and the effects of the alloying elements on the hardfacing properties were determined. The results indicate that these alloys contain martensite, austenite and $\mathrm{NbC}$ phases. As the $\mathrm{C}, \mathrm{Cr}$ and $\mathrm{Nb}$ mass fraction in the surfacing material increases, the austenite and $\mathrm{NbC}$ contents increase, and the martensite content decreases. The $\mathrm{NbC}$ crystallite size in the surface layer affects its hardness and thus its wear resistance. The wear resistance first increases and reaches to its maximum value which is 5.7 times higher than that of the C45E4 steel substrate, while by higher increasing of the mentioned elements, it decreases.

Keywords: open-arc overlaying, high carbon ferrochrome, in-situ synthesis, $\mathrm{NbC}$, hardness, wear resistance.
\end{abstract}

\section{INTRODUCTION}

When a roller press is used in composite surfacing manufacturing, the surfacing material on the squeeze roller must be carefully selected to ensure adequate wear resistance, corrosion resistance and other properties. During operation, the roller surface is in constant frictional contact with the pulverized raw material or clinker and is subject to the loading effect; thus, wear is an important cause of failure of the squeeze roller surface.

The wear resistance, hardness and fracture toughness of the surfacing alloy are influenced by the matrix type, carbide volume fraction, spatial orientation, and morphology [1-3] to improve the wear resistance of the roller surfacing materials used in composite surfacing manufacturing, researchers have added various carbideforming elements, such as tungsten [4, 5], vanadium [6, 7], niobium [8-11], titanium [12-14] and boron [15], to them. The toughness and wear resistance of a surfacing layer that contains one of these carbides can be improved by controlling the morphology and matrix structure of the carbide phase, which would extend the service life of the coated part.

In welding metallurgy, adding $\mathrm{Nb}$ to an alloy results in the formation of an $\mathrm{NbC}$ phase with a high melting point and a hardness of $2800 \mathrm{HV}$, which is substantially higher than that of other carbides. Thus, the presence of $\mathrm{Nb}$ improves the hardness and wear resistance of the alloy. Numerous groups have investigated adding $\mathrm{Nb}$ to highchromium cast iron [8-11]; however, strengthening of the wear-resistant surfacing layer by adding $\mathrm{Nb}$ to alloy steel to obtain $\mathrm{NbC}$ has rarely been addressed.

The alloy steel employed in this work was modified with niobium, chromium, titanium, silicon and manganese to strengthen the martensite matrix. This alloy steel has a surface hardness as high as $850 \mathrm{HV}_{0.2}$ and good wear resistance, therefore, it is currently the main material used to repair squeeze rollers in roller presses. In this paper selected the $\mathrm{Nb}$-containing alloy system to study the effects of the carbon and chromium contents on the microstructure and wear resistance of the deposited metal. In this paper varied the carbon and chromium contents of the flux-cored wire by changing the high-carbon ferrochromium mass fraction under the assumption, that the main components of the surfacing alloy remained the same. Thus, the surfacing alloy could be optimized. Furthermore, this investigation provides information for improving the cost-performance ratio of welding materials.

\section{EXPERIMENTAL MATERIALS AND METHODS}

C45E4 steel $(200 \mathrm{~mm} \times 150 \mathrm{~mm} \times 10 \mathrm{~mm}$; composition shown in Table 1) was used as the substrate. To prepare the welding material, six different high-carbon ferrochrome self-protecting flux-cored wires with a diameter of $2.8 \mathrm{~mm}$ were fabricated using various mass fractions of the high-carbon ferrochrome and reduced iron powder starting materials. The high-carbon ferrochrome mass fractions, the surfacing alloy compositions and the sample serial numbers are given in Table 2.

*Corresponding author. Tel.: +86-15144304510.

E-mail address: huangfei80616@126.com (F. Huang) 
Table 1. Chemical composition of the C45E4 steel used in the present study (wt.\%)

\begin{tabular}{|c|c|c|c|c|c|c|c|c|}
\hline $\mathrm{C}$ & $\mathrm{Si}$ & $\mathrm{Mn}$ & $\mathrm{S}$ & $\mathrm{P}$ & $\mathrm{Cr}$ & $\mathrm{Ni}$ & $\mathrm{Cu}$ & $\mathrm{Fe}$ \\
\hline $0.42-0.50$ & $0.17-0.37$ & $0.50-0.80$ & $\leq 0.035$ & $\leq 0.035$ & $\leq 0.25$ & $\leq 0.25$ & $\leq 0.25$ & $\mathrm{Bal}$ \\
\hline
\end{tabular}

Table 2. Addition of the high carbon ferrochrome and composition of the surfacing layers (wt.\%)

\begin{tabular}{|c|c|c|c|c|c|c|c|c|c|c|c|}
\hline $\begin{array}{c}\text { No. of the wire } \\
\text { and test sample }\end{array}$ & $\begin{array}{c}\text { High carbon ferrochrome } \\
\text { addition, wt\% }\end{array}$ & $\mathrm{C}$ & $\mathrm{Cr}$ & $\mathrm{Si}$ & $\mathrm{Mn}$ & $\mathrm{S}$ & $\mathrm{P}$ & $\mathrm{Nb}$ & $\mathrm{Ni}$ & $\mathrm{Al}$ & $\mathrm{Fe}$ \\
\hline 1 & 0 & 1.07 & 0.08 & 0.50 & 1.33 & 0.008 & 0.023 & 4.55 & 0.09 & 0.009 & $\mathrm{Bal}$ \\
\hline 2 & 2.5 & 1.25 & 0.77 & 0.53 & 1.31 & 0.013 & 0.019 & 4.63 & 0.10 & 0.014 & $\mathrm{Bal}$. \\
\hline 3 & 5 & 1.29 & 1.33 & 0.53 & 1.32 & 0.009 & 0.027 & 4.62 & 0.09 & 0.013 & Bal. \\
\hline 4 & 7.5 & 1.32 & 2.00 & 0.55 & 1.23 & 0.009 & 0.026 & 4.80 & 0.09 & 0.014 & Bal. \\
\hline 5 & 10 & 1.33 & 2.61 & 0.55 & 1.31 & 0.012 & 0.026 & 4.98 & 0.11 & 0.012 & $\mathrm{Bal}$. \\
\hline
\end{tabular}

Table 3. Process parameters of flux-cored wire hardfacing

\begin{tabular}{|c|c|c|c|c|c|}
\hline $\begin{array}{c}\text { Voltage } \\
\mathrm{U}, \mathrm{V}\end{array}$ & $\begin{array}{c}\text { Current } \\
\mathrm{I}, \mathrm{A}\end{array}$ & $\begin{array}{c}\text { Welding speed } \\
\mathrm{V}, \mathrm{cm} \cdot \mathrm{min}^{-1}\end{array}$ & $\begin{array}{c}\text { Electrode extension } \\
\mathrm{L}, \mathrm{mm}\end{array}$ & $\begin{array}{c}\text { Interlayer temperature } \\
\mathrm{T},{ }^{\circ} \mathrm{C}\end{array}$ & Post weld state \\
\hline $27.5 \sim 28.5$ & $320 \sim 350$ & 42 & $15 \sim 20$ & 200 & Air-cooling \\
\hline
\end{tabular}

The Fe-C-Cr-Nb surfacing alloy was prepared by arc surfacing using an NBC-630 inverter self-shielded welding machine. The welding parameters are listed in Table 3.

The samples were cut, ground, polished and etched with a picric hydrochloric acid alcohol solution after surfacing. Samples were prepared for both metallographic and transmission electron microscopic observation. The microstructures and phase compositions of the samples were analysed by scanning electron microscopy (SEM; EVO18), energy-dispersive X-ray spectroscopy (EDS; Link ISIS), transmission electron microscopy (TEM; JEM-2100F), and $\mathrm{X}$-ray diffraction (XRD; D/Max 2500PC, $\mathrm{Cu} \mathrm{K} \alpha$ radiation, $\lambda=0.15418 \mathrm{~nm}, 4 \% \mathrm{~min})$. The microhardness $(\mathrm{HV})$ of the surfacing layer was measured using a microhardness tester (MH-3). The load and loading time were $0.2 \mathrm{~kg}$ and $10 \mathrm{~s}$, respectively. To investigate the wear performance, the substrate and samples were cut into cylinders with a diameter of $6 \mathrm{~mm}$ and a height of $8 \mathrm{~mm}$ and placed in a pintype rotary abrasive tester (ML-100). A rotational speed of $60 \mathrm{rpm}$, an applied load of $17 \mathrm{~N}$, and a testing time of $10 \mathrm{~min}$ were used in these experiments. The surfacing layer was abraded with 360-mesh silicon carbide ( $\mathrm{SiC}$ ) sandpaper, and the wear resistance was determined based on the mass loss.

\section{RESULTS AND DISCUSSION}

\subsection{X-ray diffraction (XRD) analysis}

Fig. 1 shows the XRD patterns of the surfacing layers obtained using surfacing materials with different highcarbon ferrochromium mass fractions. The surfacing layer is mainly composed of martensite, austenite, $\mathrm{NbC}$ and $\mathrm{MC}$ $(\mathrm{M}=\mathrm{Fe}, \mathrm{Cr})$. As the high-carbon ferrochromium mass fraction increases, the $\mathrm{C}$ and $\mathrm{Cr}$ contents of the surfacing layer increase gradually and the $\mathrm{NbC}$ and $\mathrm{MC}$ diffraction peak intensities tend to increase. The original flux-cored wire does not contain $\mathrm{NbC}$; therefore, the $\mathrm{NbC}$ phase in the surfacing layer is synthesized in situ during the surfacing process. Furthermore, the martensite peak intensity decreases, whereas the austenite peak intensity clearly increases with increasing high-carbon ferrochromium content. This change in the phase composition affects the wear resistance and microhardness of the surfacing layer.

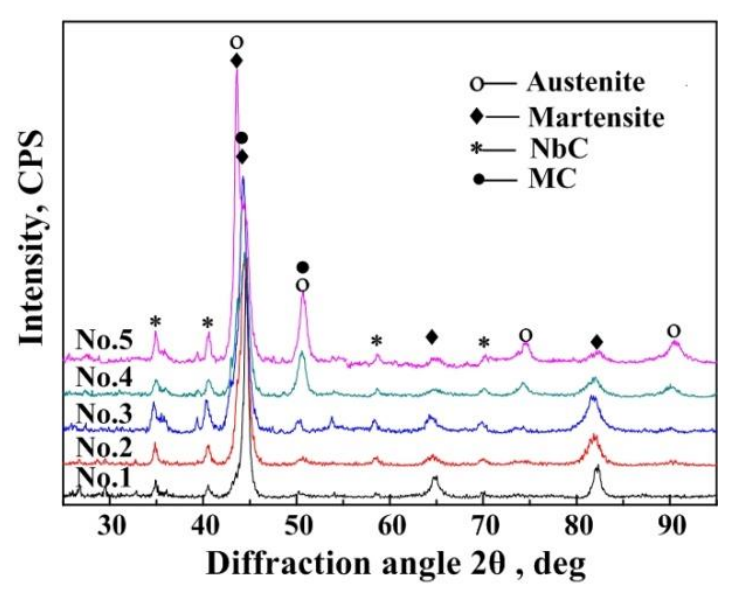

Fig. 1. XRD patterns of hardfacing alloys with various highcarbon ferrochrome additions

\subsection{Microstructural analysis}

Fig. 2 shows the microstructures of the surfacing layers fabricated with different high-carbon ferrochromium ratios (Nos. 1, 3 and 5). As shown in Fig. 2 a, the bulk phase $\left(B_{1}\right)$ of the No. 1 surfacing layer is mainly distributed in isolated granules throughout the lamellar $\left(\mathrm{C}_{1}\right)$ and dark-grey matrix (A) phases. As the high-carbon ferrochrome mass fraction increases, the bulk $\left(\mathrm{B}_{2}\right)$ and lamellar $\left(\mathrm{C}_{2}\right)$ phases grow substantially, and the dark-grey matrix phase (D) appears in the lamellar phase and gradually grows, as demonstrated by the images of samples 3 and 5 in Fig. 2 b and c, respectively. Based on the XRD and EDS analysis results (Fig. 1 and Table 4, respectively) and the $\mathrm{Fe}-\mathrm{Cr}-\mathrm{C}$ ternary phase diagram [16], the bulk phases $\left(\mathrm{B}_{1}, \mathrm{~B}_{2}\right)$ are $\mathrm{NbC}$, and the lamellar phases $\left(\mathrm{C}_{1}, \mathrm{C}_{2}\right)$ consist of a martensite and residual austenite mixture. The increase in the carbon content of the surfacing layer with increasing high-carbon ferrochromium mass fraction promotes $\mathrm{NbC}$ nucleation and growth; the $\mathrm{NbC}$ particle size increases from $1 \mu \mathrm{m}$ to $3 \mu \mathrm{m}$. Moreover, the increase in the chromium content results in a gradual increase in the amount of austenite and a corresponding decrease in the amount of martensite phase. As shown in Table 4, the carbon signal of the detector is very low because it is a light element. 


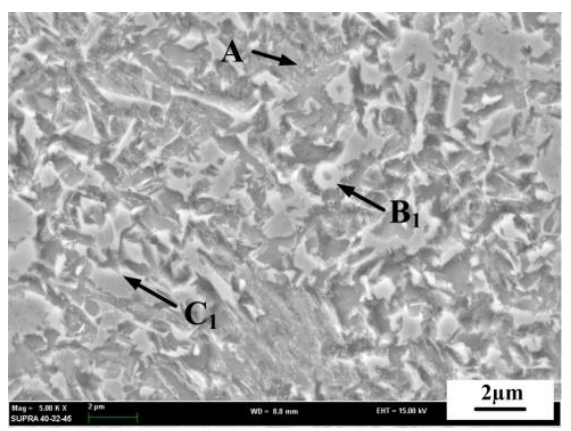

a

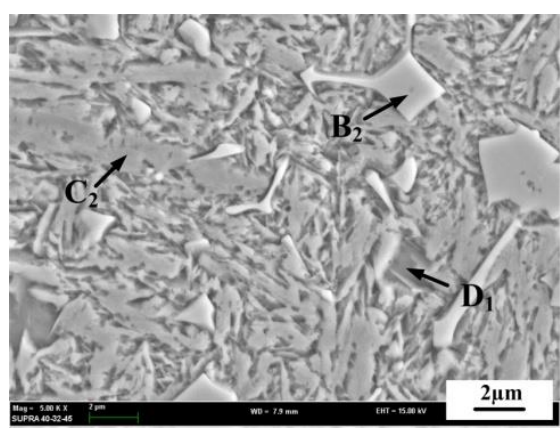

b

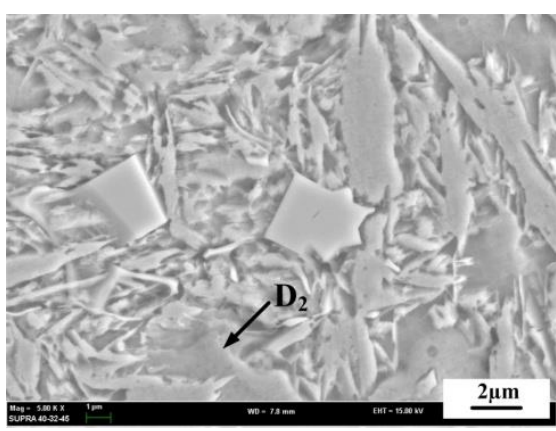

c

Fig. 2. SEM images of different surfacing layers: a-No. 1; b-No. 3; c-No. 5

Table 4. EDS analysis results for different surfacing layers (wt.\%)

\begin{tabular}{|c|c|c|c|c|c|c|c|c|}
\hline \multirow{2}{*}{ Point } & \multicolumn{7}{|c|}{ Main chemical compositions } & \multirow{2}{*}{ Phase or microstructure } \\
\hline & $\mathrm{C}$ & $\mathrm{Cr}$ & $\mathrm{Nb}$ & $\mathrm{Mn}$ & $\mathrm{Ti}$ & $\mathrm{Si}$ & $\mathrm{Fe}$ & \\
\hline A & 3.40 & 3.52 & 0.37 & 1.48 & - & 0.48 & Bal. & Ferrite \\
\hline $\begin{array}{l}\mathrm{B}_{1} \\
\mathrm{~B}_{2}\end{array}$ & $\begin{array}{l}18.42 \\
22.47\end{array}$ & - & $\begin{array}{l}72.57 \\
77.57\end{array}$ & - & $\begin{array}{l}4.32 \\
6.34\end{array}$ & - & Bal. & $\mathrm{NbC}$ \\
\hline $\mathrm{C}_{1}$ & 3.97 & 2.54 & 0.58 & 1.76 & & 0.77 & & \\
\hline $\mathrm{C}_{2}$ & 3.63 & 4.74 & 0.45 & 1.89 & - & 0.82 & Bal. & Martensite and retained austenite \\
\hline$D_{1}$ & 7.34 & 3.52 & 0.11 & 2.47 & 0.35 & 0.56 & Bal. & Ind nond ant on \\
\hline $\mathrm{D}_{2}$ & 7.15 & 3.26 & 0.15 & 2.17 & 0.36 & 0.51 & Bal. & Independent austenite \\
\hline
\end{tabular}

In addition, the test sample and vacuum system are susceptible to contamination by foreign carbon species during the experiment. Therefore, the carbon contents listed in Table 4 are only qualitative references.

Fig. 3 shows the microstructure and EDS scan of the No. 3 upper surfacing layer.

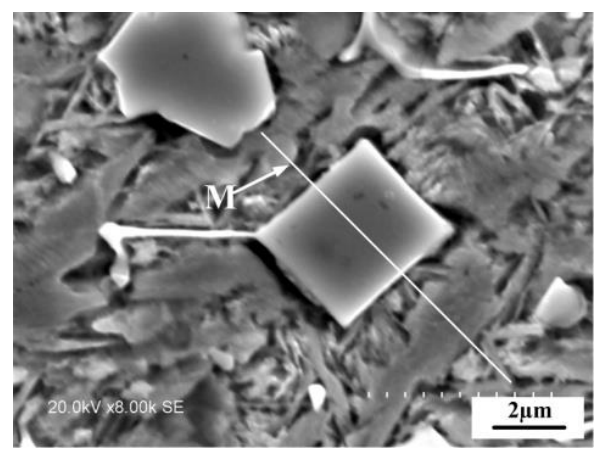

a

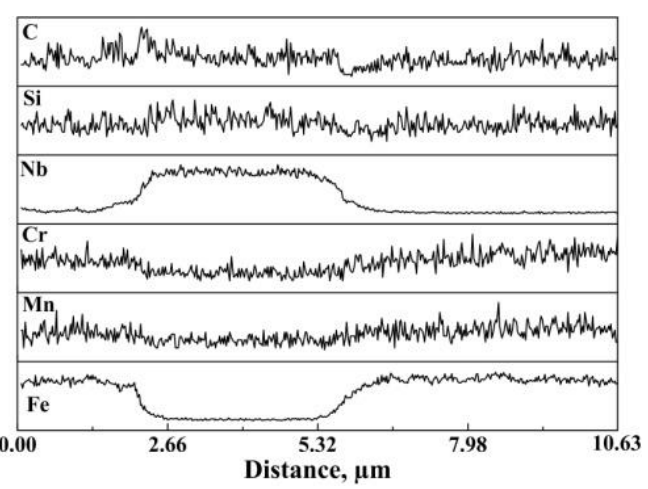

b

Fig. 3. SEM image and EDS analysis results for the surfacing layer of sample No. 3: a-SEM image; b-the element distribution along line $\mathrm{M}$
As shown in Fig. 3 a, white granules, rods and bulk phase regions are embedded in the lamellar matrix. When the carbon and chromium content of the surfacing layer increases, $\mathrm{NbC}$ will nucleate in the metallurgical reaction. $\mathrm{NbC}$ can grow freely after taking into $\mathrm{Nb}$ and $\mathrm{C}$ atoms. However, the lacking of them have inhibited its growth thus causing the $\mathrm{NbC}$ white granules and rods are small. The EDS analysis in Fig. 3 b reveals that the white regions are $\mathrm{NbC}$ and that martensite and residual austenite are uniformly distributed throughout the surfacing layer, making them difficult to distinguish from each other, Therefore, the surfacing-layer microstructure was further studied by TEM.

Fig. 4 shows the TEM images of the bulk and lamellar phases of sample No. 3 and the corresponding electron diffraction patterns. As indicated in Fig. 4 a, the bulk phase is $\mathrm{NbC}$. Notably, the interface between $\mathrm{NbC}$ and the substrate is narrow, clean and defect-free and $\mathrm{NbC}$ is synthesized in situ during surfacing. Fig. $4 \mathrm{~b}$ indicates that the martensite and residual austenite matrix have the following structure: the martensite $<111>$ axis is parallel to the austenite <001> axis, and the martensite (110) plane is parallel to the austenite (020) plane, forming a coherent relation.

\subsection{Surfacing alloy performance}

The microhardness was measured at three points every $300 \mu \mathrm{m}$ along the direction from the matrix to the surfacing layer, and the three measurements were averaged to obtain the data presented in Fig. 5 a. In this Fig, the dashed line is the fusion line. The average microhardness of the C45E4 steel is $240 \mathrm{HV}_{0.2}$, which is slightly lower than that of the heat-affected zone $\left(280 \mathrm{HV}_{0.2}\right)$. The microhardness of the surfacing layer increases substantially in the interfacial region, and it is slightly lower near the fusion line than at the middle of the surfacing layer. 


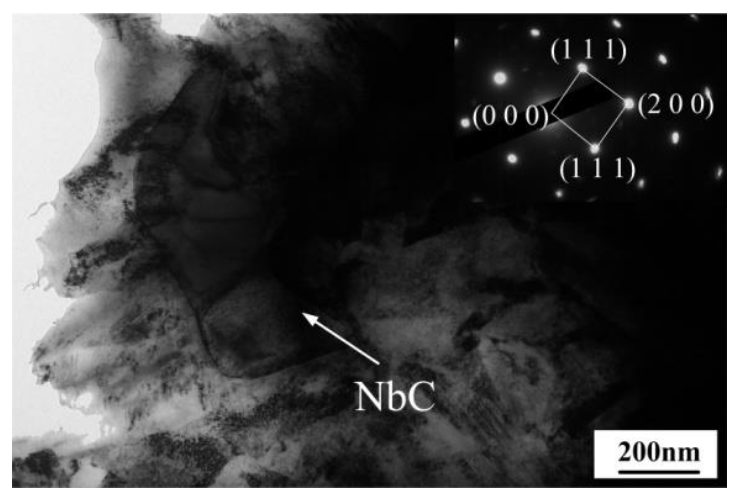

a

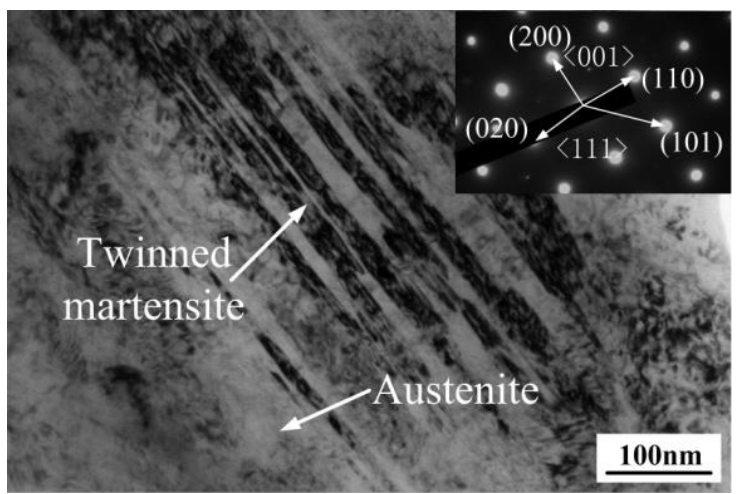

b

Fig. 4. TEM images of the surfacing layers of sample No. 3: $\mathrm{a}-\mathrm{NbC}$ formed in situ; $\mathrm{b}-$ the coherent lattice relationship of martensite and austenite

The microhardness is then essentially constant between the midpoint and the surface because the matrix does not dilute the surfacing layer in this region (the dilution of the surfacing layer by the matrix gradually decreases from the fusion line to the middle of the layer). When the surfacing layer is fabricated in the absence of high-carbon ferrochromium, the $\mathrm{NbC}$ particles are small $(1 \mu \mathrm{m})$. In this case, the average microhardness is only $500 \mathrm{HV}_{0.2}$. When high-carbon ferrochromium is added to the system, the microhardness of the surfacing layer clearly increase due to the formation of numerous well-dispersed, larger $(3 \mu \mathrm{m})$ $\mathrm{NbC}$ particles during surfacing. In particular, when the added high carbon ferrochrome is up to $5 \%$, the increase in the carbon content of the surfacing layer with increasing high-carbon ferrochromium mass fraction promotes $\mathrm{NbC}$ nucleation and growth, the martensite and retained austenite phases grow substantially, the NbC particle size increases from $1 \mu \mathrm{m}$ to $3 \mu \mathrm{m}$. $\mathrm{NbC}$ will become larger and also boast a higher hardness so that it is able to improve the hardness and the wear resistance of the surfacing layer. Adding $5 \%$ of high-carbon ferrochrome to the surfacing material results in an increase in the microhardness of the surfacing layer to as high as $850 \mathrm{HV}_{0.2}$, which is more than 3.5 times that of the C45E4 steel substrate. However, adding greater amounts of high-carbon ferrochrome to the system leads to an increase in the austenite content of the surfacing layer and, thus, to a gradual decrease in the microhardness.

Fig. $5 \mathrm{~b}$ shows the wear of the matrix and the surfacing layer. As the amount of high-carbon ferrochrome added to the system increases, the wear resistance of the surfacing layer first increases and then decreases, which is mostly consistent with the microhardness results for the surfacing layer. In one literature report [17], a martensitic matrix and an $\mathrm{NbC}$ phase were found to be the main components of an $\mathrm{Fe}-\mathrm{C}-\mathrm{Cr}-\mathrm{Nb}$ alloy steel coating prepared by laser cladding. The fabricated wear-resistant layer consisted of fine particles and had a maximum hardness of $620 \mathrm{HV}$ when the $\mathrm{Nb}$ content was $0.71 \mathrm{wt} \%$. When the $\mathrm{Nb}$ content was increased to $1.03 \mathrm{wt} \%$, the hardness and thus the wear resistance of the surfacing layer decreased. In the present work, the prepared $\mathrm{Fe}-\mathrm{Cr}-\mathrm{C}-\mathrm{Nb}$ alloy steel has a similar microstructure, and the trends in the hardness and wear resistance are the same.

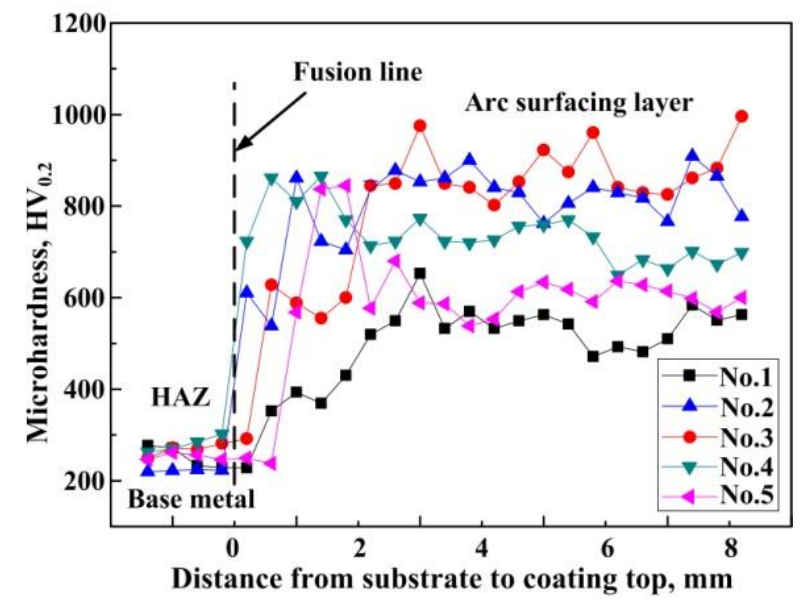

a

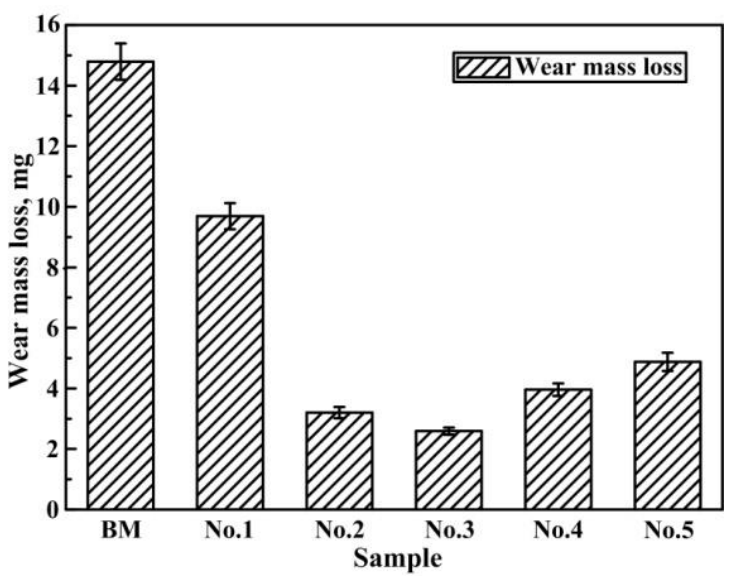

b

Fig. 5. Microhardness and wear mass loss of different surfacing layers: $a$-microhardness; $b$-average wear mass loss

As shown in Fig. 5 b, the least surfacing-layer wear is observed for sample No. 3. The mass loss of the surfacing layer due to wear is approximately $2.59 \mathrm{mg}$, whereas that of the matrix is $14.79 \mathrm{mg}$, demonstrating that the wear resistance of the surfacing layer can be as high as 5.7 times that of the substrate. SEM images of the wear morphologies of the substrate and different surfacing layers are shown in Fig. 6 (the dashed line shows the wear direction). After wear, the substrate is uniformly covered with wide channels, which span the entire field of view (Fig. 6 a), indicating that the abrasive particles do not encounter strong resistance during the wear process. In contrast, the channels observed on sample No. 1 after wear are substantially narrower. 


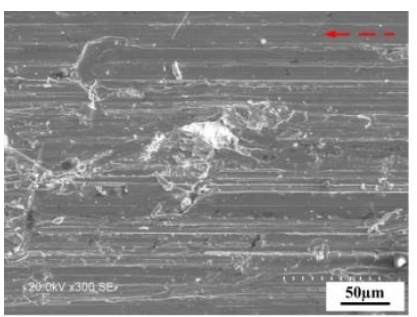

a

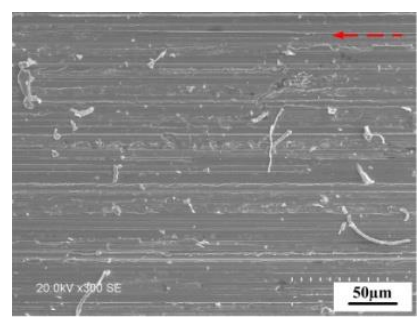

$\mathrm{b}$

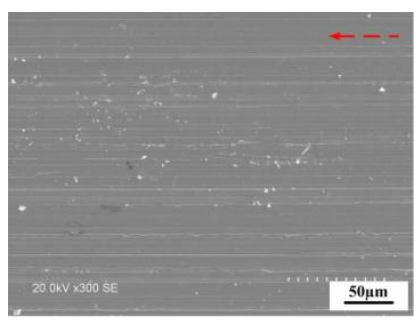

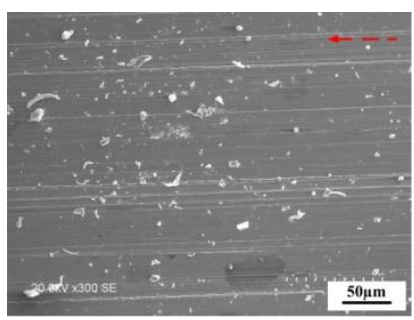

Fig. 6. Wear morphology of the base metal and different surfacing layers: $a$-base metal; b-sample No. 1; c-sample No. 3; d-sample No. 5

However, because the particle size of the $\mathrm{NbC}$ hard phase in the surfacing layer is small, the overall improvement in the wear resistance is limited, as shown in Fig. 6 b. Fig. $6 \mathrm{c}$ shows the wear morphology of the No. 3 surfacing layer.

The channels are small and shallow; as they encounter the dispersive resistance of the NbC particles $(3 \mu \mathrm{m})$, they become shallower and even disappear in some cases, clearly demonstrating a substantial improvement in the wear resistance [9]. As the high-carbon ferrochrome content increases, martensite precipitation decreases, whereas austenite precipitation increases, as shown in Fig. 2 c. Therefore, the wear resistance of the No. 5 surfacing layer is lower than that of the No. 3 sample; channels remain on the No. 5 surfacing layer, as shown in Fig. $6 \mathrm{~d}$. A comparison of the No. 3 and No. 5 surfacing layers after wear shows that the number and size of the channels in the No. 3 sample are smaller than those in the No. 5 sample. Evidently, the presence of martensite and $\mathrm{NbC}$ particles in the surfacing layer substantially improves its overall wear resistance. However, the increase in austenite precipitation with increasing high-carbon ferrochromium content eventually leads to a decrease in the wear resistance of the surfacing layer; therefore, the amount of high-carbon ferrochrome used in the surfacing material must be optimized.

\section{CONCLUSIONS}

In this paper the influence of the high-carbon ferrochrome mass fraction on the microstructure evolution, microhardness and wear properties of the hardfacing alloys were investigated. The main research results are summarized as follows:

1. The hardfacing layer prepared in this work is composed of martensite, austenite, and a $\mathrm{NbC}$ hard phase embedded in the matrix. As the high-carbon ferrochromium mass fraction in the surfacing material increases, the total amount of precipitated $\mathrm{NbC}$ increases and the $\mathrm{NbC}$ particle size gradually increases from $1 \mu \mathrm{m}$ to $3 \mu \mathrm{m}$ and then remains constant. Furthermore, the martensite content decreases, whereas the austenite content gradually increases.

2. The NbC particles are synthesized in situ during surfacing. The interface between these particles and the substrate is narrow, clean and defect-free. The martensite $\langle 111\rangle$ axis is parallel to the austenite $\langle 001\rangle$ axis, and the martensite (110) plane is parallel to the austenite (020) plane, forming a coherent relation.
3. The addition of high-carbon ferrochromium to the surfacing material substantially improves the wear resistance of the surfacing layer. When the amount of high-carbon ferrochromium added to the material is $5 \%$, the mechanical properties of the surfacing layer are optimal; the average microhardness of the upper surfacing layer is $850 \mathrm{HV}_{0.2}$, and the wear resistance was at its highest value, about 5.7 times higher than that of the base metal. However, as the high-carbon ferrochromium content is further increased, austenite precipitation increases, leading to a decrease in the wear resistance of the surfacing layer. Therefore, the amount of high-carbon ferrochrome added to the surfacing material should be optimized.

\section{Acknowledgments}

The work was supported by Jilin City Science and Technology Innovation and Development Plan Project, China (Grant No. 20190104143).

\section{REFERENCES}

1. Tabrett, C.P., $\quad$ Sare, I.R., $\quad$ Ghomashchi, M.R. Microstructure-property Relationships in High Chromium White iron Alloys International Materials Reviews 41 (2) 1996: pp. 59-82. https://doi.org/10.1179/095066096790326075

2. Lu, L., Soda, H., McLean, A. Microstructure and Mechanical Properties of $\mathrm{Fe}-\mathrm{Cr}-\mathrm{C}$ Eutectic Composites Materials Science \& Engineering A $347(1-2)$ 2003: pp. $214-222$. https://doi.org/10.1016/s0921-5093(02)00588-9

3. Chenje, T.W., Simbi, D.J., Navara, E. Relationship between Microstructure, Hardness, impact Toughness and Wear Performance of Selected Grinding Media for Mineral ore Milling Operations Materials \& Design 25 (1) 2004: pp. $11-18$. https://doi.org/10.1016/S0261-3069(03)00168-7

4. Guo, J., Liu, S., Zhou, Y., Wang, J., Xing, X., Ren, X., Yang, Q. Stability of Eutectic Carbide in Fe-Cr-Mo-W-V-C Alloy Materials Letters 171 2016: pp. 216-219. https://doi.org/10.1016/j.matlet.2016.02.054

5. Lv, Y., Sun, Y., Zhao, J., Yu, G., Shen, J., Hu, S. Effect of Tungsten on Microstructure and Properties of High Chromium Cast Iron Materials \& Design 39 2012: pp. 303-308. https://doi.org/10.1016/j.matdes.2012.02.048

6. Filipovic, M., Romhanji, E., Kamberovic, Z., Korac, M. Matrix Microstructure and Its Micro-Analysis of Constituent Phases in As-Cast Fe-Cr-C-V Alloys Materials Transactions 50 (10) 2009: pp. 2488-2492. 
https://doi.org/ 10.2320/matertrans.M2009002

7. Filipovic, M., Romhanji, E. Strain Hardening of Austenite in $\mathrm{Fe}-\mathrm{Cr}-\mathrm{C}-\mathrm{V}$ Alloys Under Repeated Impact Wear $270(11-12)$ 2011: pp. 800-805. https://doi.org/10.1016/j.wear.2011.02.006

8. Correa, E.O., Alcântara, N.G., Valeriano, L.C., Barbedo, N.D., Chaves, R.R. The Effect of Microstructure on Abrasive Wear of a $\mathrm{Fe}-\mathrm{Cr}-\mathrm{C}-\mathrm{Nb}$ Hardfacing Alloy Deposited by the Open Arc Welding Process Surface and Coatings Technology 276 2015: pp. 479-484. https://doi.org/10.1016/j.surfcoat.2015.06.026

9. Filipovic, M., Kamberovic, Z., Korac, M., Gavrilovski, M. Microstructure and Mechanical Properties of $\mathrm{Fe}-\mathrm{Cr}-\mathrm{C}-\mathrm{Nb}$ White Cast Irons Materials \& Design 47 2013: pp. $41-48$. https://doi.org/10.1016/j.matdes.2012.12.034

10. Huang, F., Ren, Z.A., Liu, W., Chen, H., Zheng, S. Effects of Graphite Additions on Microstructures and Wear Resistance of Fe-Cr-C-Nb Hardfacing Alloys Materials Science 23 (3) 2017: pp. 233-237. https://doi.org/10.5755/j01.ms.23.3.16678

11. Zhi, X., Xing, J., Fu, H., Xiao, B. Effect of Niobium on the As-Cast Microstructure of Hypereutectic High Chromium Cast Iron Materials Letters $62(6-7)$ 2008: pp. $857-860$. https://doi.org/10.1016/j.matlet.2007.06.084

12. Liu, H.Y., Yu, F.B., Meng, Q.S., Chen, S.P., Wang, H. Microstructure and Properties of $\mathrm{Fe}-\mathrm{Cr}-\mathrm{C}$ Hardfacing Alloys
Reinforced With TiC-TiB2 Science and Technology of Welding and Joining 17 (5) 2012: pp. 419-423. https://doi.org/10.1179/1362171812Y.0000000028

13. Zhi, X., Xing, J., Fu, H., Gao, Y. Effect of Titanium on the As-Cast Microstructure of Hypereutectic High Chromium Cast Iron Materials Characterization 59 (9) 2008: pp. $1221-1226$. https://doi.org/10.1016/j.matchar.2007.10.010

14. Zhi, X., Xing, J., Gao, Y., Fu, H., Peng, J., Xiao, B. Effect of Heat Treatment on Microstructure and Mechanical Properties of a Ti-Bearing Hypereutectic High Chromium White Cast Iron Materials Science and Engineering: A 487 (1-2) 2008: pp. $171-179$. https://doi.org/10.1016/j.msea.2007.10.009

15. Tasgin, Y., Kaplan, M., Yaz, M. Investigation of Effects of Boron Additives and Heat Treatment on Carbides and Phase Transition of Highly Alloyed Duplex Cast Iron Materials \& Design 30 (8) 2009: pp. 3174-3179. https://doi.org/10.1016/j.matdes.2008.11.015

16. Tabrett, C.P., $\quad$ Sare, I.R., $\quad$ Ghomashchi, M.R. Microstructure-property Relationships in High Chromium White Iron Alloys International Materials Reviews 41 (2) 1996: pp. 59-82. https://doi.org/10.1179/imr.1996.41.2.59

17. Yang, J., Huang, J., Fan, D., Chen, S. Microstructure and Wear Properties of $\mathrm{Fe}-6$ wt. $\% \quad \mathrm{Cr}-0.55$ wt. $\%$ $\mathrm{C}-\mathrm{X}$ wt. $\% \mathrm{Nb}$ Laser Cladding Coating and the Mechanism Analysis Materials \& Design 88 2015: pp. 1031-1041. https://doi.org/10.1016/j.matdes.2015.09.108

(c) Huang et al. 2021 Open Access This article is distributed under the terms of the Creative Commons Attribution 4.0 International License (http://creativecommons.org/licenses/by/4.0/), which permits unrestricted use, distribution, and reproduction in any medium provided you give appropriate credit to the original author(s) and the source, provide a link to the Creative Commons license, and indicate if changes were made. 